\title{
VALIDASI PROSES PRODUKSI SEBAGAI BAGIAN IMPLEMENTASI LEAN MANUFACTURING DI INDUSTRI FARMASI
}

\author{
Thomas Aquino Aditya Widhiswastiawan \\ Fakultas Farmasi Universitas Pancasila-Jakarta \\ widhiswastiawan@gmail.com
}

\begin{abstract}
The national pharmaceutical industry is facing increasing competition, cost pressures and the effectiveness of its manufacturing operations. Lean manufacturing offers methods, tools and programs to increase productivity. While the pharmaceutical industry must apply CPOB aspect, one of which validation process. The objective of this study is to prove the process validation is part of lean manufacturing implementation. The result is the application of process validation, the waste that mentioned in lean manufacturing is over process and re-working can be avoided.
\end{abstract}

Keywords: lean manufacturing, process validation, waste

\begin{abstract}
ABSTRAK
Industri farmasi nasional sedang menghadapi persaingan yang meningkat, tekanan biaya dan keefektifan kinerja operasi manufakturnya. Lean manufacturing menawarkan metode, alat dan program untuk meningkatkan produktivitas. Sedangkan industri farmasi wajib menerapkan apa yang sudah diatur didalam $\mathrm{CPOB}$, salah satunya validasi proses. Penelitian ini bertujuan untuk membuktikan bahwa validasi proses merupakan bagian dari implementasi lean manufacturing. Hasilnya adalah dengan penerapan validasi proses, pemborosan yang disebutkan dalam lean manufacturing yaitu proses berlebih dan re-working bisa dihindarkan.
\end{abstract}

Kata Kunci : lean manufacturing, validasi proses, pemborosan

\section{PENDAHULUAN}

Implementasi Jaminan Kesehatan Nasional (JKN) yang merupakan bagian dari Sistem Jaminan Sosial Nasional (SJSN) seperti yang diamanatkan dalam Undang-Undang Nomor 40 Tahun 2014 adalah bersifat wajib, memberikan dampak kepada peta bisnis farmasi di Indonesia. Sebelumnya tidak pernah ada sistem asuransi kesehatan besar seperti Badan Penyelenggara Jaminan Sosial (BPJS) Kesehatan. Badan tersebut memberikan perhatian terhadap harga dan kualitas obat. Hanya perusahaan farmasi yang produknya memenuhi persyaratan legal dan aspek teknis Cara Pembuatan Obat yang Baik (CPOB), serta harga bersaing yang bisa terdaftar dalam daftar produk yang digunakan oleh BPJS Kesehatan. Dengan demikian, industri farmasi di Indonesia mau tidak mau harus mengambil pangsa pasar ini (Sampurno, 2016).

Penurunan ongkos produksi menjadi pilihan bagi perusahaan farmasi yang mengambil pangsa pasar asuransi BPJS ini, karena selain masalah kualitas produk, harga juga sangat menentukan. Dengan demikian, perusahaan dituntut menjalankan operasi pabrik dengan efisien agar dapat menurunkan ongkos produksi.

Untuk menghasilkan produk dengan harga yang kompetitif, namun tetap menjaga keamanan, kualitas dan khasiat obat. Maka diperlukan strategi khusus yang perlu diambil, salah satunya adalah lean manufacturing. Lean Manufacturing atau lean production, merupakan sebuah metodologi praktek produksi yang fokus kepada penggunaan dan pemberdayaan sumber daya untuk menciptakan nilai bagi pelanggan. Caranya adalah dengan menghilangkan pemborosan yang terjadi pada proses, sehingga proses yang terjadi lebih efektif dan efisien, dengan kualitas produk yang lebih baik (Gasperz, 2007).

Fokus utama dari lean manufacturing adalah menghilangkan waste (pemborosan) dalam proses, dan di dalam konsepnya terdapat tujuh macam waste (aktivitas tanpa nilai tambah dari sudut pandang pelanggan) yang umumnya terjadi, dan harus dihilangkan. Tujuh pemborosan tersebut diantaranya :

1. Transportasi (Pemborosan ini terdiri dari pemindahan atau pengangkutan yang tidak diperlukan seperti penempatan sementara, penumpukan kembali, perpindahan barang). 
2. Kelebihan Persediaan (Inventory, stok atau persediaan yang berlebihan).

3. Gerakan (Motion, pemborosan ini berupa waktu yang digunakan untuk mencari, kemudian menunggu barang datang, dsb).

4. Kelebihan Produksi (Over Production, menghasilkan produk melebihi permintaan ataupun lebih awal dari jadwal).

5. Proses Berlebih (Over Processing, penambahan proses yang tidak diperlukan bagi barang produk hanya akan menambah biaya produksi).

6. Cacat produk (Rework, kerja ulang tidak ada nilai tambahnya) (Anonim, 2016).

Sistem lean manufacturing kemudian menjadi pilihan bagi industri farmasi di Indonesia dalam upaya mengefektifkan dan mengefisiensikan proses produksi mereka. Beberapa di antara industri farmasi bahkan membuat departemen khusus, untuk mengaplikasikan sistem lean manufacturing. Padahal konsep lean manufacturing sendiri telah terwakili didalam $\mathrm{CPOB}$, yang wajib diaplikasikan oleh setiap pelaku industri farmasi. Salah satu bagian yang merupakan implementasi dari lean manufacturing di dalam CPOB yaitu Validasi Proses. Tujuan pelaksanaan dari validasi proses adalah:

1. Memberikan dokumentasi secara tertulis bahwa prosedur yang berlaku dan digunakan dalam proses produksi, senantiasa mencapai hasil yang diinginkan secara terus menerus.

2. Mengurangi masalah yang mungkin terjadi selama proses produksi.

3. Memperkecil kemungkinan terjadinya proses ulang (reworking) (Priyambodo, 2012).

Berdasarkan latar belakang tersebut, maka dilakukan penelitian untuk mengetahui peran validasi proses dalam implementasi lean manufacturing di salah satu perusahaan farmasi berskala multinasional yang berlokasi di Jawa Barat.

\section{METODE}

Penelitian ini dilakukan dengan cara mengambil data produk tablet un-coated yang dilakukan validasi proses pengemasan primer (stripping) pada periode tahun 2016-2017 dan data penyimpangan mutu (yang terkait dengan produk yang divalidasi tersebut) di tahun 2016-2017. Validasi pengemasan primer dilakukan, karena adanya perubahan jenis alufoil dari 20 micron menjadi 15 micron, untuk semua kemasan primer produk tersebut.

\section{HASIL DAN PEMBAHASAN}

\subsection{Data Produk yang Divalidasi}

\begin{tabular}{|c|l|c|c|}
\hline Nama Produk & Status Validasi & Penyimpangan Mutu & Nomor Bets \\
\hline Tablet A & Selesai (diterima) & - & - \\
\hline Tablet B & Selesai (diterima) & - & - \\
\hline Tablet C & Selesai (diterima) & - & - \\
\hline Tablet D & Belum selesai & terdapat 187 strip ditemukan bocor & AA024 \\
\hline Tablet E & Belum selesai & - & - \\
\hline \multirow{2}{*}{ Tablet F } & Belum selesai & terdapat 94 strip ditemukan bocor & SA017 \\
\cline { 3 - 4 } & $\begin{array}{l}\text { terdapat 56 strip terbuka (alufoil } \\
\text { tidak saling menempel) }\end{array}$ & XA023 \\
\hline Tablet G & Selesai (diterima) & - & - \\
\hline
\end{tabular}

Gambar 1. Data produk tablet un-coated yang divalidasi proses pengemasan primer dan penyimpangan mutu yang terjadi (2016-2017)

Berdasarkan data diatas, tablet yang telah selesai divalidasi dan hasilnya masuk persyaratan yang telah ditetapkan (tablet $\mathrm{A}$, tablet $\mathrm{B}$, tablet $\mathrm{C}$ dan tablet $\mathrm{G}$ ), tidak ditemukan penyimpangan mutu pada tahun 2016-2017. Sedangkan untuk tablet $\mathrm{D}$ dan tablet $\mathrm{F}$ (belum selesai validasi) terdapat penyimpangan, kecuali tablet $\mathrm{G}$. 
Jurnal Inkofar* Volume 1 No. 2, Desember 2017 * ISSN: 2615-3645 (Print) / 2581-2920 (Online)

Tersedia secara online di: http://www.politeknikmeta.ac.id/meta/ojs/

\subsection{Tindakan Perbaikan}

\begin{tabular}{|c|c|l|}
\hline Nama Produk & Nomor Bets & \multicolumn{1}{c|}{ Tindakan } \\
\hline Tablet D & AA024 & Sortir $100 \%$ dan re-stripping \\
\hline \multirow{2}{*}{ Tablet F } & SA017 & Sortir $100 \%$ dan re-stripping \\
\cline { 2 - 3 } & XA023 & Sortir $100 \%$ dan re-stripping \\
\hline
\end{tabular}

Gambar 2. Data Produk Tablet yang dilakukan Proses Berlebih dan Proses Ulang (reworking)

Untuk seluruh produk yang mengalami penyimpangan mutu, seperti ada gambar 2. Dilakukan proses perbaikan, yaitu dengan melakukan sortir $100 \%$ hasil strip di lini pengemasan primer dan dilakukan stripping ulang untuk strip yang bocor.

Berdasarkan data 1, seluruh produk tablet (A, B, C, dan G) yang telah selesai divalidasi pengemasan primernya, tidak terdapat penyimpangan mutu. Selesai validasi berarti keseluruhan proses pengemasan primer telah memenuhi persyaratan penerimaan yang telah ditetapkan. Sedangkan untuk produk yang belum selesai validasi, berarti terdapat pengulangan proses validasi karena persyaratan penerimaan belum terpenuhi. Karena secara persyaratan dari regulator (Badan Pengawas Obat dan Makanan-RI) mewajibkan untuk dilakukan pada tiga bets berturut-turut. Kecuali untuk produk tablet E karena baru dilakukan satu kali validasi (belum selesai tiga bets berturut-turut) dan tidak ditemukan penyimpangan. Produk tablet $\mathrm{D}$ dan $\mathrm{F}$ yang mengalami penyimpangan mutu, harus dilakukan perbaikan. Sama seperti yang disebutkan dalam konsep lean manufacturing yaitu terdapat tujuh macam pemborosan. Pada produk tersebut dilakukan rework (re-stripping) dan proses berlebih (pensortiran 100\% terhadap seluruh hasil stripping).

Dari data dan uraian data diatas, dapat diketahui bahwa dengan adanya validasi proses, maka dapat dihindarkan adanya waste (pemborosan) dari proses pengemasan primer. Ongkos produksi (factory overhead) yang dikeluarkan akan meningkat karena ada aktivitas perbaikan yaitu penggunaan listrik pada mesin, HVAC/sistem tata udara dan penerangan. Biaya tenaga kerja langsung (operator produksi) juga bertambah karena pembayaran lembur untuk proses sortir $100 \%$ hasil strip dan restripping. Serta bahan kemas tambahan yang digunakan untuk proses re-stripping.

Selain itu ada beberapa intangible cost yang muncul akibat pemborosan tersebut, antara lain:

1. Keterlambatan pasokan ke pasaran akibat adanya penyimpangan mutu tersebut

2. Biaya pemusnahan bahan kemas hasil sortir yang tidak bisa digunakan lagi

3. Tablet yang rusak akibat proses sortir dan defoil (mengeluarkan obat dari kemasan strip)

4. Biaya sampling dan pemeriksaan ulang hasil pengemasan primer

\section{KESIMPULAN DAN SARAN}

Validasi proses sebagai salah satu persyaratan wajib yang harus dipenuhi oleh setiap industri farmasi dalam memproduksi obat, merupakan salah satu wujud implementasi konsep lean manufacturing. Dengan melaksanakan validasi proses yang benar dan tepat pada setiap produk yang dihasilkan, maka secara langsung perusahaan dapat mencegah munculnya proses berlebih dan re-working.

Hasil validasi proses yang telah diterima dan selesai, dituangkan didalam catatan pengemasan bets maupun dokumen pendukung lain, wajib dilaksanakan oleh seluruh bagian yang terkait dengan proses manufaktur dengan penuh integritas.

\section{DAFTAR PUSTAKA}

Anonim. 2012. Pedoman Cara Pembuatan Obat yang Baik. Jakarta. Badan Pengawas Obat dan Makanan Republik Indonesia

Anonim. 2016. The Seven Wastes of Lean, www.leanmanufacturingtools.org, diakses tanggal 15 Oktober 2017.

Gasperz,V. 2007, Lean Six Sigma for Manufacturing and Service Industries. Jakarta. Gramedia Pustaka Utama.

Priyambodo, B. 2012, Validasi Proses (Paradigma Baru : Pendekatan "Lifecycle"), www.priyambodo1971.wordpress.com, diakses tanggal 17 Oktober 2017.

Sampurno. 2016. Prospek Industri Farmasi Indonesia. Seminar Nasional dan Oral Presentation. Yogyakarta. Fakultas Farmasi Universitas Gadjah Mada. 